\title{
Play therapy dengan permainan tradisional "bentengan" efektif meningkatkan kemampuan interaksi sosial siswa saat pandemi Covid-19
}

\author{
Septi Anaitulloh ${ }^{1 *}$ ), Sutijono ${ }^{2}$, \& Dimas Ardika Miftah Farid $^{3}$ \\ Universitas PGRI Adi Buana Surabaya ${ }^{123}$ \\ *) Alamat korespondensi: Ds.Simoketawang Dsn.Tawangsari Rt.05 Rw.02, Sidoarjo, 61261, Indonesia; E-mail: \\ septixis128@gmail.com
}

Article History: Received: 31/03/2021;

Revised: 21/06/2021;

Accepted: 21/06/2021;

Published: 30/06/2021.

How to cite:

Anaitulloh, S., Sutijono, \& Farid, D.A.M. (2021). Play therapy dengan permainan tradisional "bentengan" efektif meningkatkan kemampuan interaksi sosial siswa saat pandemi Covid-19. Teraputik: Jurnal Bimbingan dan Konseling, 5(1), pp. 40-47. DOI: 10.26539/teraputik.51607

\footnotetext{
(c) (i) This is an open distributed access article under the Creative Commons 4.0 Attribution License, which permits unrestricted use, distribution, and reproduction in any medium, provided the original work is properly cited. (c) 2021, Anaitulloh, S., Sutijono, \& Farid, D.A.M. (s).
}

\begin{abstract}
Abstrak: Tujuan penelian ini adalah untuk mengetahui pengaruh play therapy dengan permainan tradisional "Bentengan" dalam bimbingan kelompok terhadap kemampuan interaksi sosial siswa saat pandemi Covid-19 di SMP Islam Al Amal Surabaya. Metode penelitian menggunaakan rancangan penelitian pre- eksperimental one group pre- test dan post- test. Subjek penelitian sebanyak 8 siswa yang memiliki interaksi sosial sangat rendah dan rendah. Pengujian hipotesis yang digunakan oleh peneliti yaitu wilcoxon signed ranks test. Hasil penelitian yang dilakukan oleh peneliti, menunjukkan bahwa ada perbedaan yang signifikan dari interaksi sosial antara pre -test dan post- test dimana interaksi sosial pada post -test lebih tinggi dari pre-test yang artinya play therapy dengan permainan tradisional "Bentengan" dalam bimbingan kelompok berpengaruh terhadap kemampuan interaksi sosial ( $Z=-2.524$; Asymp. $\mathrm{Sig}=0.012<\alpha=0.05$ ). Berdasarkan hasil penelitian ini, play therapy dengan permainan tradisional "Bentengan" dalam bimbingan kelompok berpengaruh terhadap kemampuan interaksi sosial saat pandemi Covid-19 di SMP Islam Al Amal Surabaya.
\end{abstract}

Kata Kunci: Terapi Bermain, Bentengan, Interaksi Sosial

Abstract: The purpose of this study was to see the effect of playing therapy with the traditional game "Bentengan" in group guidance on student social interactions during the Covid-19 Pandemic at Al Amal Islamic Junior High School in Surabaya. The research method used a preexperimental research design one group pre-test and post-test. The research subjects were 8 students who had very low and low social interaction. Hypothesis testing used by researchers is the rank test signed by Wilcoxon. The results of the research conducted by the researcher showed that there was a significant difference in social interaction between the pre-test and post-test where the social interaction on the post-test was higher than the pre-test, which means that playing therapy with the traditional game "Bentengan" in group guidance. influence on social interaction interactions $(Z=-2.524$; Asymp. Sig $=0.012<\alpha=0.05)$. Based on the results of the study, playing therapy with the traditional game "Bentengan" in group guidance has an effect on social interactions during the Covid-19 pandemic at Al Amal Islamic Junior High School in Surabaya.

Keywords: Play Therapy, Bentengan, Social Interaction

\section{Pendahuluan}

Masa Pandemi Covid-19 memberikan efek akan sikap sosial terhadap masyarakat yang dimana perseorangan memutuskan untuk menjauh dari kehidupan sosial pada saat ini. Akibat dari menjauhnya dari kehidupan sosial mengakibatkan terjadinya kelompok sosial, aturan, dan norma baru yang muncul seperti membedakan kedudukan (stratafikasi sosial). Dampak dari pandemi Covid-19 dikalangan masyarakat terbagi menjadi beberapa bidang seperti sosial, pariwisata, ekonomi, dan pendidikan (Shofiana, 2020). Pada saat ini pendidikan dilakukan melalui pembelajaran jarak jauh (PJJ) yang dilaksanakan di rumah. Pembelajaran yang awalnya dilakukan secara langsung dengan bertatap muka di sekolah kini berganti dilakukan secara daring (online) yang dimana guru pengajar dan siswa dituntut untuk menguasai metode pembelajaran daring (online). 
Pembelajaran daring (online) ditengah pandemi Covid-19 banyak memunculkan masalah di masyarakat. Permasalahan yang muncul salah satunya yaitu dalam pendidikan, dimana kurangnya persiapan pembelajaran daring yang matang dilakukan para tenaga pendidik mempunyai dampak terhadap penerimaan materi oleh peserta didik yang seringkali tidak memahami materi ataupun penyampaian dari guru (Sania, 2020). Dari wawancara guru bk SMP Islam Al Amal Surabaya mejelaskan banyaknya keluhan akibat pembelajaran daring ini, yang dimana guru bk menyampaikan materi kepada siswanya hanya melalui pesan grup dengan aplikasi whatsapp. Sehingga banyaknya siswa yang kurang paham akan materi yan disampaikan. Tidak hanya kurangnya materi pembelajaran yang disampaikan, interaksi sesama teman/guru menurun juga menjadi masalah didalam jenjang pendidikan.

Pandemi Covid- 19 yang dikala ini menyerang dunia utamanya Indonesia, secara umum kehidupan warga banyak menempuh pergantian, garis besarnya proses interaksi sosial yang menempuh pergantian baik dari segi sistem Social Statics (statika sosial ataupun struktur sosial) serta Social dynamic (dinamika sosial) (Siti, 2020). Interaksi sosial tidak dapat berjalan apabila (1) tidak adanya kontak antara perseorangan satu dengan perseorangan yang lainnya dan (2) tidak adanya komunikasi secara langsung, jika permasalahan tersebut tidak segera diatasi maka seorang individu tidak akan mempunyai rasa sosial yang tinggi diantara sesama manusia (Dewi, 2014). Permasalahan tentang kemampuan interksi sosial pada siswa harus segera diatasi agar mengetahui bahwa sanyainteraksi sosial sangat berpengaruh besar terhadap kehidupan (Dewi, 2014).

Interaksi ialah kebutuhan dasar untuk manusia sebab mereka merupakan makhluk sosial yang hendak tetap bersentuhan dengan orang lain, alam, serta makhluk lain. Dalam proses interaksi sosial, penyesuaian diri ialah salah satu aktivitas yang tidak bisa dihindari. Interaksi sosial ialah proses yang berkaitan dengan sikap kelompok secara totalitas anggota ke orang lain (Subandi et al., 2020). Hubungan antara individu dan kelompok bisa pengaruhi, mengganti ataupun tingkatkan sikap orang lain serta kebalikannya termasuk interaksi sosial bagi (Subandi et al., 2020).

Penindakan permasalahan yang terpaut dengan interaksi sosial yang rendah butuh memperoleh atensi spesial dengan sesuatu proses bimbingan. Bimbingan konseling ialah salah satu proses dalam satuan pembelajaran yang berfungsi dalam membagikan dorongan kepada siswa yang memiliki hambatan ataupun permasalahan dalam belajar ataupun sosial. Secara universal layanan tutorial kelompok memiliki tujuan buat pengembangan keahlian bersosialisasi, serta lebih spesialnya layanan bimbingan kelompok bertujuan buat mendesak pengembangan perasaan, akal, anggapan, pengetahuan, serta perilaku yang mendukung perwujudan tingkah laku yang lebih efisien, ialah kenaikan keahlian berbicara baik secara verbal ataupun nonverbal (Dewi, 2014). Metode play therapy merupakan salah satu metode yang bisa dterapkan dalam layanan bimbingan kelompok.

Play therapy adalah terapi yang dilakukan oleh seorang professional untuk membantu menyelesaikan masalah anak dengan melakukan aktivitas bermian (Bratton dan Dafoe, 2015). Adapun tujuan dari teknik permainan dalam bimbingan kelompok yaitu sebagai proses belajar dalam mengembangkan keterampilan sosial siswa dalam mengalamai pengalaman-pengalaman seperti hubungan interpersonal siswa, keterampilan dalam pengambilan keputusan, meperbaiki hubungan antar siswa, dan melampiaskan ketegangan-ketegangan yang terjadi sehingga siswa dapat berkembang secara psikis, fisik, maupun emosi (Rici dan Alawiyah, 2019). Permainan memiliki fungsi sebagai menyehatkan mental, fisik, maupun emosional seseorang, terdapat dua macam jenis permainan yakni permainan modern dan tradisional.

Indonesia ialah salah satu negeri yang mempunyai macam permainan tradisional, dimana anak-anak Indonesia sebagian besar masih terdapat yang memainkannya, walaupun dikala ini telah banyak permainan modern yang tersebar. Permainan tradisional di Indonesia sangat bermacam-macam salah satunya merupakan permainan Bentengan. Permainan tradisional bentengan digunakan dalam layanan bimbingan kelompok sebab permanan tersebut telah diketahui oleh warga Indonesia, sehingga bila diterapkan dalam dalam layanan bimbingan kelompok siswa tidak lagi merasa asing dengan permaina tersebut. Terdapat sebagian aspek 
42 Play therapy dengan permainan tradisional "bentengan" efektif meningkatkan kemampuan interaksi sosial siswa saat pandemi Covid-19

keahlian sosial yang didapatkan kala anak memainkan game tradisional bentengan ialah, (1) ketrampilan dalam berkerjasama, (2) menyesuikan diri, (3) berinteraksi, (4) menotrol diri, (5) berempati, serta (6) menghargai orang lain (Kurniati, 2016). Dengan begitu permainan tradisional bentengan bisa tingkatkan interaksi sosial anak buat bersosialisasi dengan orang yang disekitarnya.

Permainan tradisional Indonesia pula diucap selaku permainan rakyat yang sarat hendak nilai pembelajaran serta kepribadian. Permainan tradisional tidak cuma melatih kecerdasan dengan bijak, namun pula mendidik anak emosional serta spiritual, menanamkan toleransi, gotong royong, keluarga serta keberanian dalam hidup (Aribowo dan Hidayah, 2019). Pertumbuhan raga sangat erat kaitannya dengan pertumbuhan motorik anak. Pendidikan motorik dapat dimaksud selaku proses pendidikan yang menuju pada ukuran gerak (Hasbi, dan Sukoco, 2014).

Penelitian ini bertujuan untuk mengetahui pengaruh play therapy dengan permainan tradisional "Bentengan" dalam bimbingan kelompok terhadap kemampuan interaksi sosial saat pandemi Covid-19 di SMP Islam Al Amal Surabaya.

\section{Metode}

Penelitian ini yakni penelitian pre-eksperimental dalam wujud one group pre-test serta pots- test. Subyek diobservasi 2 kali (pre- test serta post- test), pre- test saat sebelum dicoba perlakuan serta post- test sehabis dilakulkan perlakuan. Perolehan pre- test serta post- test menjabarkan lewat uji $\mathrm{T}$, berikut rancangan penelitian.

\begin{tabular}{|ll|}
\hline $\mathrm{T}_{1}$ & $\mathrm{X}_{\mathrm{t}}$ \\
\hline
\end{tabular}

Keterangan:

Gambar 1. Rancangan Penelitian

$\mathrm{T}_{1}=$ Nilai pre- test (kemampuan interaksi sosial siswa saat sebelum diberi perlakuan).

$\mathrm{X}_{\mathrm{t}}=$ Treatment (perlakuan yang diberikan berbentuk play therapy dengan permainan tradisional"Bentengan" dalam bimbingan kelompok terhadap kemampuan interaksi sosial siswa dikala pandemi covid-19).

$\mathrm{T}_{2}=$ Nilai post- test (kemampuan interaksi sosial siswa sehabis diberi perlakuan).

$\mathrm{T}_{1}$ merupakan pengukuran variabel terikat yaitu interaksi sosial siswa. Variable ini ditakar dengan memakai skala siswa yang dikembangkan oleh peneliti. Setelah itu, dilakukan perlakuan (treatment) yaitu pemberian berupa play therapy dengan permainan tradisional "Bentengan" dalam bimbingan kelompok $\left(\mathrm{X}_{\mathrm{t}}\right)$. Setelah perlakuan selesai, kemudian diukur variabel terikat dengan menggunakan instrument yang sama $\left(T_{2}\right)$.

Populasi yakni keseluruhan objek atau subjek yang ada pada suatu wilayh dan mencukupi syarat-syarat tertentu bersambungan dnegan persoalan peneltian, maupun keutuhan atau perseorangan dalam ruang linkup yang akan diteliti Mertono (Setiawan dan Lianawati, 2020). Penelitian ini mengenakan populasi siswa kelas $8^{3}$ yang berjumlah 25 siswa dengan total siswa perempun 15 serta jumlah serta laki- laki 10. Sampel yang dipilih adalah siswa yang mempunyai interaksi sosial yang kurang, dengan menggunakan metode purposive sampling.

Tata cara pengumpulan data pada penelitian ini memakai instrument angket penelitian yang menggunakan skala pengukuran yaitu skala likert. Sosiometri juga dapat digunakan sebenarnya (Bilqis, 2018). Namun, penelitian ini lebih memilih menggunakan angket. Hal ini dikarenakan instrument angket memiliki pola yang lebih sesuai preferensi penelitian interaksi sosial. Skala pengukuran interaksi sosial telah diujicobakan kepada 25 responden kemudian hasilnya akan dianalisis dengan kolerasi item soal untuk menguji validitas butir item dengan syarat yang di gunakan dalam uji validitas ini menggunkan koefisien sama dnegan $(=) 0,5$ ataupun lebih (sangat kecil 0,5). Apabila kurang dari 0,5 butir dalam instrument dinyatakan tidak 
valid. Sedangkan analisis data penelitian menggunakan uji hipotesis menggunakan Uji Wilcoxon pada SPSS Versi 26.0.

\section{Hasil dan Diskusi}

Penelitian menyajikan yang diperoleh setelah melakukan pre-test yang diberikan kepada 25 siswa, dimana menggunakan 8 siswa sebagai sampel penelitian yang memiliki interaksi sosial yang rendah. Rincan tersebut diuraikan sebagai berikut.

Tabel 1. Hasil Skor Pre-test Terendah

\begin{tabular}{ccccc}
\hline No & $\begin{array}{c}\text { Nama } \\
\text { Responden }\end{array}$ & L/P & $\begin{array}{c}\text { Hasil } \\
\text { Pre-test }\end{array}$ & Kategori \\
\hline 1 & NF & P & 80 & Kurang \\
\hline 2 & APW & L & 72 & Kurang \\
\hline 3 & MNN & L & 63 & Sangat Kurang \\
\hline 4 & HS & P & 65 & Sangat Kurang \\
\hline 5 & FB & P & 65 & Sangat Kurang \\
\hline 6 & SNLK & P & 63 & Sangat Kurang \\
\hline 7 & SH & P & 65 & Sangat Kurang \\
\hline 8 & MF & L & 60 & Sangat Kurang \\
\hline
\end{tabular}

Berdasarkan tabel 1 ditentukan jumlah responden sejumlah 8 siswa yang mempunyai interaksi sosial yang kurang. Setelah itu peneliti menindak lanjuti dengan pemberian treatment yaitu pemberikan teknik play therapy dengan permainan tradisional "Bentengan" dalam bimbingan kelompok sebanyak 6 kali pertemuan.

Setelah pemberian treatment dengan teknik play therapy dengan permainan tradisional "Bentengan" dalam bimbingan kelompok, Ada pula hasil pot- test, berikut.

Tabel 2. Hasil Skor Post- test

\begin{tabular}{cccc}
\hline No & $\begin{array}{c}\text { Nama } \\
\text { Responden }\end{array}$ & L/P & Hasil Post-Test \\
\hline 1 & NF & P & 104 \\
\hline 2 & APW & L & 104 \\
\hline 3 & MNN & L & 89 \\
\hline 4 & HS & P & 89 \\
\hline 5 & FB & P & 85 \\
\hline 6 & SNLK & P & 97 \\
\hline 7 & SH & P & 84 \\
\hline 8 & MF & L & 84 \\
\hline
\end{tabular}

Data tabel 1 menjelaskan hasil sebelum diberikan treatment dan tabel 2 sesudah diberikan treatment. Terdapat perubahan pada skor interaksi sosial siswa setelah diberikan 6 kali treatment menggunakan teknik play therapy dengan permainan tradisional "Bentengan" dalam bimbingan kelompok. Dilihat pada tabel 2 yang mengalami kenaikan nilai dan perubahan kategori yang semula berkategori kurang jadi sangat tingi serta kategori sangat kurang menjadi tinggi. Dilihat pada tabel 3 terdapat 2 siswa yang berinisial NF dan APW, pre-test memiliki kategori kurang dan perubahan pada post-test menjadi sangat tinggi dengan perbedaan 24 dan 32, untuk 6 siswa yaitu MNN, HS, FB, SNLK, SH, MF memliki perubahan kategori dan berbedaan skor 26, 24, 20, 34, 19, 24. 
44 Play therapy dengan permainan tradisional "bentengan" efektif meningkatkan kemampuan interaksi sosial siswa saat pandemi Covid-19

Untuk memperkuat perubahan yang ada pada tabel 3, dan mengetahui perubahan skor dan signifikansinya, maka peneliti memakai bantuan SPSS for windows versi 26 untuk mengetahui hasil dari uji Wilcoxon, berikut adalah tabel uji Wilcoxon.

Tabel 3. Uji Wilcoxon - Ranks

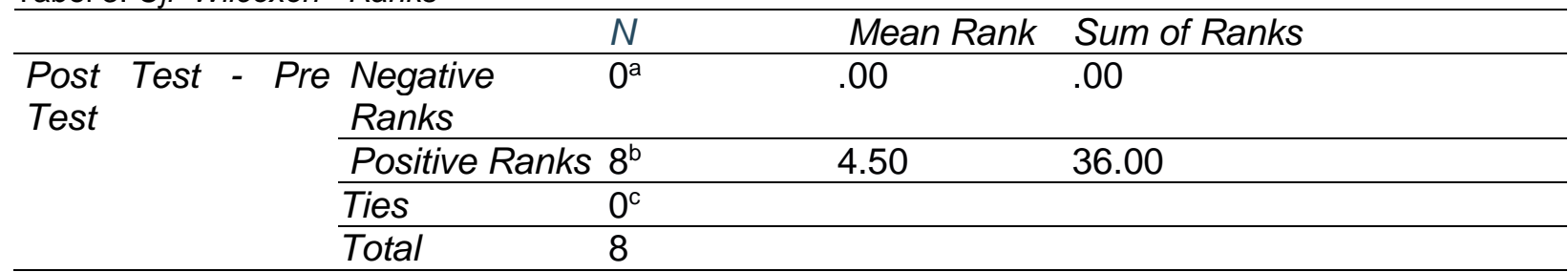
a. Post Test < Pre Test
b. Post Test $>$ Pre Test
c. Post Test $=$ Pre Test

Tabel 4. Test Statistics ${ }^{a}$

\begin{tabular}{cr}
\hline & Post Test - Pre Test \\
\hline $\mathrm{Z}$ & $-2.524^{\mathrm{b}}$ \\
\hline $\begin{array}{l}\text { Asymp. Sig. } \\
\text { (2-tailed) }\end{array}$ & .012 \\
\hline
\end{tabular}

a. Wilcoxon Signed Ranks Test

b. Based on negative ranks

Berlandaskan hasil penelitian di atas, menunjukkan peningkatan persentase pada setiap responden. Masing-masing responden mengalami perubahan dari kategori sangat rendah ke tinggi dan sangat tinggi. Perubahan nilai yang terjadi pada kedelapan responden tersebut disebabkan beberapa faktor yang melatarbelakangi masing-masing responden tidak sama antara kondisi dan sebab yang melatarbelakangi.

a. Konseli NF

Hasil pada pre-test konseli NF yaitu 80 dan post-test 104 dengan perbedaan skor 24. Pada pertemuan pertama konseli merespon dengan baik, meskipun sedikit malu-malu. Untuk pertemuan kedua hingga ketiga koseli mulai aktif dan pertemuan keempat hingga enam konseli sangat aktif disetiap kegiatan.

b. Konseli APW

Hasil pada pre-test konseli APW yaitu 72 dan post-test 104 dengan perbedaan skor 32 . Selama mengikuti treatment, konseli merupakan cukup aktif dan ikut memberi pendapat. Pertemuan pertama hingga pertemuan keenam, konseli selalu aktif menjawab dan bertanya kepada konselor.

c. Konseli MNN

Hasil pada pre-test konseli APW yaitu 63 dan post-test 89 dengan perbedaan skor 26 . Pada pertemuan pertama dan kedua, konseli kurang aktif, tetapi pada pertemuan ketiga hingga keempat mulai sedikit aktif dan pertemuan kelima hingga keenam konseli aktif dalam memberikan pendapat kepada anggota kelompok.

d. Konseli HS

Hasil pada pre-test konseli HS yaitu 65 dan post-test 89 dengan perbedaan skor 24 . Pertemuan pertama dan kedua, konseli kurang aktif dalam mengikuti kegiatan. Pada pertemuan ketiga sidikit aktif tetapi masih malu, dan pertemuan keempat hingga keenam konseli mulai aktif dalam menyangga dan memberikan solusi.

e. Konseli FB 
Hasil pada pre-test konseli FB yaitu 65 dan post-test 85 dengan perbedaan skor 20. Pada pertemuan pertama hingga pertemuan ketiga konseli kurang aktif. Setelah pemberian materi mengenai interaksi sosial, konseli mulai aktif hingga keenam. Konseli dapat berinteraksi dengan anggota kelompok dan mengungkapkan pendapat.

\section{f. SNLK}

Hasil pada pre-test konseli SNLK yaitu 63 dan post-test 97 dengan perbedaan skor 34 . Selama menjalankan treatment konseli SNLK merupakan anggota yang cukup aktif bahkan selalu ceria dan mampu bercanda dengan anggota kelompok yang lain, konseli SNLK mampu membuat situasi kelompok menjadi menyenangkan.

g. Konseli SH

Hasil pada pre-test konseli SH yaitu 65 dan post-test 84 dengan perbedaan skor 19. Pertemuan pertama konseli tidak aktif dalam mengikuti kegiatan, dan pada pertemaun kedua konselor menjelaskan meteri mengenai interksi sosial, setelah pemberian materi ada perubahan dari konseli yaitu mulai ada interaksi dengan anggota kelompok dan menyapa jika bertemu.

h. Konseli MF

Hasil pada pre-test konseli MF yaitu 60 dan post-test 84 dengan perbedaan skor 24 . Konseli MF tidak aktif dalam pertemuan pertama hingga ketiga yang dimana hanya berdiam diri. Pada pertemuan keempat yaitu melakukan treatment permainan tradisional bentengan konseli MF ada perubahan hingga akhir pertemuan.

Interaksi sosial sangat penting karena memengaruhi aspek perkembangan yang lainnya, baik karier, belajar, dan pribadi. Menurut literatur yang telah ada, persepsi sangat penting dalam memengaruhi interaksi sosial (Bilqis, 2017). Dengan adanya persepsi yang baik, interaksi sosial baik, konflik pun berkurang (Bilqis, 2013). Persepsi terhadap teman dapat menjadi baik dengan melihat sisi positif teman (Bilqis et al., 2019).

Dalam suatu penelitian disebutkan bahwa play therapy lebih efektif meningkatkan daya tarik interpersonal, dengan implikasi lebih meningkatkan interaksi sosial daripada layanan bimbingan klasikal (Bilqis, 2021). Play therapy dalam bentuk kelompok sangat membantu memperbaiki persepsi positif siswa (Bilqis et al., 2017), sehingga play therapy memengaruhi interaksi sosial mereka (Saripah \& Bilqis, 2019).

Faktor lain yang mendukung adalah keharmonisan keluarga (Ratnasari \& Bilqis, 2020). Keharmonisan keluarga dapat meningkatkan self efficacy (Fitriyanti \& Bilqis, 2020b). Self efficacy dapat meningkatkan interaksi sosial yang baik pada siswa (Fitriyanti \& Bilqis, 2020a). Selain itu, daya tarik interpersonal juga menjadi dasar bagaimana interaksi sosial berawal (Bilqis, 2019c). Play therapy dapat meningkatkan daya tarik interpersonal, sehingga interaksi sosial tercapai dengan baik. Pribadi rasional tidak mudah tersinggung juga meningkatkan interaksi sosial yang baik (Bilqis, 2019a). Salah satu caranya adalah dengan bantuan guru Bimbingan dan Konseling (Bilqis, 2019b).

\section{Simpulan}

Dari hasil peneltian, diperoleh hasil kalau terjadi kenaikan nilai rata- rata( mean) skor variabel interaksi sosial pada $\mathrm{N}=8$. Nilai mean sebelum dilakukan layanan bimbingan kelompok sebesar 66.63 dengan standar deviasi 6.391. Sedangkan setelah dilakukan layanan bimbingan kelompok nilai mean naik menjadi 92.00 dengan standar deviasi 8.519. Hasil hipotesis menggunakan uji Wilcoxon diketahui bahwa Asymp. Sig=0, 012 perbandingan Asymp. Sing = $0,012<\alpha=0,05$ maka $\mathrm{HO}$ ditolak serta Ha diterima maksudnya adalah ditemukan pengaruh pada penggunaan play therapy dengan permainan tradisional "Bentengan" dalam bimbingan kelompok terhadap kemampuan interaksi sosial siswa.

\section{Ucapan Terima Kasih}


46 Play therapy dengan permainan tradisional "bentengan" efektif meningkatkan kemampuan interaksi sosial siswa saat pandemi Covid-19

Puji dan syukur melimpah kepada Allah SWT karena atas berkat dan karunianya, akhirnya skripsi ini bisa diselesaikan. Terima kasih kepada dosen pembimbing skripsi Drs. H. Sutijono., M.M. dan Dimas Andika, S.Pd., M.Pd. Yang telah banyak meluangkan waktu, pikiran dan tenaga dengan sabar membantu dalam menyelesaikan skripsi ini; Kedua orang tua Bapak Juwandi, lbu Choiriyah, kakak saya Ika Arifina dan keluarga besar lbu Jannah yang telah mendoakan dan memberikan dukungan penuh dalam menyelesaikan skripsi ini; serta teman-teman yaitu, Kholifatul Dwinur Kholisah, Apolinarius Dari Saka, Adi Setiawan, Maharipta, yang selalu meluangkan waktu untuk membantu dalam menyelesaikan skripsi ini; Teman-teman Alumni SMP 17 yaitu, Anggi, Pury, Rais, Lely, yang membantu dalam mengerjakan skripsi ini sehingga penulisan ini dapat terselesaikan tepat pada waktunya; Teman-teman SMA, Talihta, Firdaus, Aci, Ghifari, Eka, Ria, Elfi, selalu support dalam mengerjakan skripsi ini mekipun dengan virtual; dan Teman-teman kelas saya BK A1 2017 yang selalu kompak.

\section{Daftar Rujukan}

Aribowo, D. S., \& Hidayah, T. (2019). The Effectiveness of Indonesian Traditional Games and Agility on Student's Gross Motor Skills in Elementary School Hj . Isriati Baiturrahman 2 Semarang. 8(3), 281-287.

Bilqis, F. (2013). Hubungan Antara Persepsi Dengan Cara Penyelesaian Konflik Interpersonal Pada Siswa Kelas XI Jurusan Akuntansi SMK Mahardhika. Jurnal BK UNESA, 3(1).

Bilqis, F. (2017). PERBEDAAN KEEFEKTIFAN ANTARA ADLERIAN GROUP PLAY COUNSELING DAN LAYANAN BIMBINGAN KLASIKAL DALAM MENINGKATKAN DAYA TARIK INTERPERSONAL: Penelitian Mix-Method terhadap Siswa Kelas $V$ SDN Sukasenang dan SDN Cihaurgeulis 2 Tahun Ajaran 2016/2017. Universitas Pendidikan Indonesia.

Bilqis, F. (2018). Instrumen untuk mengukur daya tarik interpersonal pada anak. TERAPUTIK: Jurnal Bimbingan Dan Konseling, 2(2), 67-77.

Bilqis, F. (2019a). Cara membangun kepribadian dominasi rasional. TERAPUTIK: Jurnal Bimbingan Dan Konseling, 2(3), 109-114.

Bilqis, F. (2019b). Pengembangan program layanan bimbingan klasikal untuk meningkatkan daya tarik interpersonal siswa kelas V Sekolah Dasar. TERAPUTIK: Jurnal Bimbingan Dan Konseling, 2(3), 123-133.

Bilqis, F. (2019c). Perbandingan profil daya tarik interpersonal berdasarkan Instrument Attraction Questioner dengan sosiometri. TERAPUTIK: Jurnal Bimbingan Dan Konseling, 3(1), 1-6.

Bilqis, F. (2021). Does Adlerian Play Therapy Increase Social, Physical, and Task Appeal More Than Content Mastery Services in Elementary School Students? Child Education Journal, 3(1), 1-18.

Bilqis, F., Karina, T., \& Latipah, I. C. (2019). Peran konselor dalam mewujudkan sekolah aman dan damai bagi siswa. TERAPUTIK: Jurnal Bimbingan Dan Konseling, 2(3), 115-122.

Bilqis, F., Taufiq, A., \& Saripah, I. (2017). The Effectiveness Differences Of Adlerian Group Play Counseling And Classroom Guidance Activity In Improving Interpersonal Attractiveness. Psikopedagogia Jurnal Bimbingan Dan Konseling, 6(2), 12-19.

Bratton, S. C., \& Dafoe, E. C. (2015). W7 R. Encyclopedia of Mental Health: Second Edition, (June), 278-283.

Dewi Ma'arufah Lucyana. (2014). The Implementation Of The Modified Traditional Hop-Scotch Game In Grup Counseling To Improve Students Social Interaction Ability In Class VII-A MTs Negeri Tulungagung. Jurnal BK, 4(3), 1-10.

Fitriyanti, E., \& Bilqis, F. (2020a). Penguasaan konten analisis doodle art meningkatkan self efficacy mahasiswa UPBK Unindra dalam memberikan layanan konseling. TERAPUTIK: Jurnal Bimbingan Dan Konseling, 4(2), 175-182.

Fitriyanti, E., \& Bilqis, F. (2020b). PKM layanan PKO analisis doodle art sebagai media self 
efficacy mahasiswa Prodi matematika \& UPBK Unindra. TERAPUTIK: Jurnal Bimbingan Dan Konseling, 4(2), 285-292.

Hasbi, \& Sukoco, P. (2014). Pengembangan model pembelajaran motorik dengan modifikasi permainan tradisional untuk sekolah dasar kelas atas. Jurnal Keolahragaan,2(1),4658.Retrievedfrom https://journal.uny.ac.id/index.php/jolahraga/article/view/2602

Kurniati, E. 2016. Permainan Tradisional Dan Perannya Dalam Mengembangkan Keterampilan Sosial Anak. Jakarta: Prenadamedia Grup.

Ratnasari, D., \& Bilqis, F. (2020). Layanan informasi untuk membangun keharmonisan keluarga pada orangtua atau wali asuh di Yayasan Jakarta Selatan. Teraputik: Jurnal Bimbingan Dan Konseling, 4(1), 35-42.

Rici, O. T. W., \& Alawiyah, T. (2019). Layanan Bimbingan Kelompok Dengan Teknik Permainan Kerjasama Untuk Meningkatkan Keterampilan Sosial Siswa. FOKUS (Kajian Bimbingan \& Konseling Dalam Pendidikan), 2(5), 44-53.

Sania, Mashabi. 2020. Update 28 Maret:102 orang meninggal akibat covid-19. Tersedia https://nasional.kompas.com/read/2020/03/28/16033311/update-28-maret-102 meninggal-akibat-covid-19. Diakses pada 12 November 2020 pukul 16.06 WIB.

Saripah, I., \& Bilqis, F. (2019). Pengembangan program Adlerian group play counseling untuk meningkatkan daya tarik interpersonal siswa kelas V Sekolah Dasar. TERAPUTIK: Jurnal Bimbingan Dan Konseling, 2(3), 141-155.

Setiawan, A., \& Lianawati, A. (2020). Bimbingan kelompok teknik homeroom efektif dalam meningkatkan motivasi belajar siswa SMP Darul Ulum Waru Sidoarjo. 4(2), 119-125. https://doi.org/10.26539/teraputik.42309

Shofiana, A. (2020). Pendidikan Daring di Masa Covid-19. Kompas.Com. Retrieved from https://www.kompas.com/edu/read/2020/08/12/112834471/pendidikan- daring-di-masacovid-19?page=all.

Siti Rahma Harahap. (2020). Proses Interaksi Sosial Di Tengah Pandemi Virus Covid 19. ALHIKMAH: Media Dakwah, Komunikasi, Sosial Dan Budaya, 11(1), 45-53. https://doi.org/10.32505/hikmah.v11i1.1837.

Subandi, S., Hasanah, I. F., Dewi, L. L., \& Jannah, S. R. (2020). Implementation of Group Counseling and Role-Playing: The Investigation of Students Social Interaction Improvement. Islamic Guidance and Counseling Journal, 3(1), 32-37.

\section{Competing interests:}

The authors declare that they have no significant competing financial, professional or personal interests that might have influenced the performance or presentation of the work described in this manuscript. 